\title{
UNIVERSITYOF
}

FORWARD

THINKING

WESTMINSTER用

WestminsterResearch

http://www.westminster.ac.uk/westminsterresearch

The Touch of Iconoclasm

Pitcher, B.

This is a copy of the accepted author manuscript of the following article: Pitcher, B.

(2018) The Touch of Iconoclasm, European Journal of Cultural Studies, First Published April 10, 2018, DOI: 10.1177/1367549418761794. The final definitive version is available from the publisher Sage at:

https://dx.doi.org/10.1177/1367549418761794

(C) The Author(s) 2018

The WestminsterResearch online digital archive at the University of Westminster aims to make the research output of the University available to a wider audience. Copyright and Moral Rights remain with the authors and/or copyright owners.

Whilst further distribution of specific materials from within this archive is forbidden, you may freely distribute the URL of WestminsterResearch: ((http://westminsterresearch.wmin.ac.uk/).

In case of abuse or copyright appearing without permission e-mail repository@westminster.ac.uk 


\title{
Title:
}

\section{The touch of iconoclasm}

\begin{abstract}
:
This article reflects on some depicted, intentional acts of iconoclasm undertaken by Isis in Northern Iraq, and viewed as online videos. It attempts to consider what makes these moving images compelling to audiences who share an orientation to the protection and preservation of ancient artefacts. In doing so it prompts a reflection on their circulation as part of stories that get told about cultural heritage, and particularly the simple civilizational oppositions that get set up between 'Western' and 'Islamic' culture. Centring on the significance of the sensation of touch to practices of cultural inscription, it suggests that the Northern Iraq videos animate forms of synaesthesic material engagement that are denied by the modernist technologies of museum culture.
\end{abstract}

\section{Keywords:}

iconoclasm, Isis, cultural heritage, touch, postcoloniality 
As I watched the rafts, until they disappeared behind a projecting bank forming a distant reach of the river, I could not forbear musing upon the strange destiny of their burdens; which, after adorning the palaces of the Assyrian kings, the objects of the wonder, and may be the worship of thousands, had been buried unknown for centuries beneath a soil trodden by Persians under Cyrus, by Greeks under Alexander, and by Arabs under the first successors of their prophet. They were now to visit India, to cross the most distant seas of the southern hemisphere, and to be finally placed in a British Museum. Who can venture to foretell how their strange career will end? - Austen Henry Layard (1857: 304). 


\section{Jihadist iconoclasm}

From the spectacle of ' $9 / 11$ ' to the caged fire and water immolations of the Islamic State (Isis), acts of violence undertaken by jihadist groups have made powerful statements in the realm of visual culture. ${ }^{1}$ As Jean-Luc Nancy suggests, 'violence always makes an image of itself' (2005: 20). In the form of terrorism, violence necessarily has a visual dimension as a physical means to symbolic ends, but the significant role of images in all forms of contemporary conflict means that among jihadist militias too we see a wider orientation to the visual. And so while the visual language of jihadism is often explicitly, selfavowedly iconoclastic, it is an iconoclasm that needs to be understood as deeply invested in the use of visual language rather than in its puritanical refusal. ${ }^{2}$ The apparent contradiction here of image-making iconoclasts is not exceptional: as WJT Mitchell notes, any prohibition on representation has to fail in that it is bound to 'represent the very thing it prohibits' (Mitchell, 2005: 297). Iconoclasm gives life to the things it targets, and acts of desecration may confer qualities of sacredness that icons might never have possessed in the first place (Taussig, 1999). Just as the emphatic rejection of images involves their reanimation, so too the most ostensibly secular gesture is part of a sacrialized visual culture: Charlie Hebdo's iconoclastic rejection of the second commandment transmutes crude caricatures into icons of 'Western values'; the rejection of the superstitious fetish is hereby transformed into an article of faith. 
Critical work on this subject conceives of iconoclasm not only as a breaking of images, but as a transformation of them. Iconomachy ('image struggle') has been used to describe 'processes that can lead to symbols being broken, conserved, disputed, or, in fact, produced' (O'Neil et al., 2014: 385). Bruno Latour (2002) coins 'iconoclash' as a way of focusing attention on the uncertainty and ambiguity that is inherent to the meaning of such processes. At an historical moment when 'heritage has turned into an image machine' (Probst, 2012: 12), it is particularly evident that creation and destruction are not absolute but relative concepts; as practices they are co-constitutive. The inevitable mediation of contemporary acts of iconoclasm ensures that we are usually dealing with translations between and proliferations across a range of different media. Iconoclasm (and its cognate neologisms) might accordingly be said to describe transformative engagements with the artefacts of visual culture that involve conflicting criteria of meaning and value. Iconoclasm draws attention to the materiality of such contestations, demonstrating that icons are never simply images alone - as if immaterial Platonic ideals - but that they are formed through and intermingled with organic and inorganic matter, whether monumental stones, servers in data centres, or spilled human blood.

This article reflects on some depicted, intentional acts of iconoclasm undertaken by Isis in Northern Iraq, and viewed as online videos. Methodologically, its focus is not on the motivations of the iconoclasts, nor on the description and interpretation of jihadist iconoclasm in the context of ongoing military and cultural conflict in Iraq and the wider Middle East. Rather, 
it attempts to explore, at a certain level of abstraction, what makes these moving images compelling to audiences who share an orientation to the protection and preservation of ancient artefacts. In this, it takes my own captivation with the spectacle of Isis iconoclasm as a starting point: these are images that I have found fascinating to look at. Mindful of the contradiction that is central to the concept of iconoclasm, I consider the possibility that similar and equivalent complexities might inhere in the protectionist desire that these images invoke in me, and which appear to be echoed in the widespread reaction to them in English language news and social media. The uneasy 'we' this article uses to elaborate a Western subject position is not going to go uncontested, but it is a heuristically useful way of exploring such complexities. Building on my own initial interest, I explore the dynamics of protection and preservation in some wider cultural manifestations - the discipline and practice of archaeology, the institutions of contemporary Western museum culture, and global cultural organizations like Unesco. In so doing, I consider some of the ways in which preservational practices involve their own varieties of violence and iconoclasm.

A more nuanced approach to the dynamics of preservation and destruction prompts a reflection on their circulation as part of stories that get told about cultural heritage, and particularly the simple civilizational oppositions that get set up between 'Western' and 'Islamic' culture. Centring on the significance of the sensation of touch to practices of cultural inscription, I suggest that the Northern Iraq videos animate forms of synaesthesic material engagement that are denied by the modernist technologies of museum culture. I go on to 
speculate that the injunction to protect and conserve describes a neurotic relationship to cultural heritage that wants to simultaneously hold onto it and make it disappear. Isis iconoclasm is so captivating, I suggest, because it stages a destruction that the avowed protectors and defenders of cultural heritage may also secretly desire.

Figure 1 around here: screengrab from Mosul video

\section{The Northern Iraq videos}

The example I want to discuss here comprises two short videos, edits of originals produced by Isis and widely published in a range of different versions on the internet in the first half of 2015. The first video, released in February (Memri TV, 2015a), apparently shows the defacement and destruction of sculpture in Mosul museum from Roman-era Hatra (dating from circa 200CE), and of bull-bodied Lamassu (giant sculptures of human-headed winged animals) at the nearby Nergal Gate at Nineveh (dating from the period of the Neo-Assyrian empire circa 700 BCE). The second video, released in April (Memri TV, 2015b), is from the archaeological site at Nimrud, located along the Tigris to the South of Mosul. It depicts the deployment of sledgehammers, angle grinders, pneumatic drills and diggers on Assyrian reliefs (dating from circa $800 \mathrm{BCE}$ ), and records the rigging of barrel bombs followed by at least two explosions across a large expanse of the site. The videos deploy basic 
production techniques familiar from other videos by Isis - the slowing down, speeding up and reversing of footage, shots placed out of sequence, postproduction sound effects and the nasheed soundtrack of processed chanting (see Said, 2012). Both videos feature a cast of excited young men $^{3}$ and the same unnamed to-camera narrator who invokes religious instruction and presents the depicted violence as avowedly iconoclastic, as in the following narration from the first video:

The Prophet Muhammad commanded us to shatter and destroy statues. This is what his companions did later on when they conquered foreign lands. Since Allah commanded us to shatter and destroy these statues, idols, and remains, it is easy for us to obey, and we do not care (what people think), even if this costs billions of dollars (Memri TV, 2015a; video includes subtitled translation from Arabic).

Although the range of intended local, regional and international audiences in these videos is complex, and is likely to have shifted over time (see C. Jones, 2015), such statements obviously rehearse the idea of contrasting and conflicting systems of meaning and value. Such iconoclasm is an attempt to reinforce the credentials of Isis against its enemies (initially other Islamic groups) by stressing a fidelity with the history of Muslim conquest. Engaged in the task of destroying icons that have been spared by those with a supposedly weaker grasp of Quranic instruction, it seeks comparison with these precedents in both religious and military terms. In doing so, Isis of course draws upon and consolidate an all-too-familiar binary logic that makes 
them the perfect antagonists of a 'secular' West: not just zealotry versus weak or absent faith, but the 'medieval' Salafist inspiration of Muhammad and the Rashidun Caliphate brought into contrast with Western modernity, a strictly monotheistic singularity versus the rhetoric of pluralist tolerance, and the precedence of religious instruction over alternative moralities born of capital or culture. Those identifying with either 'side' in this crudely-drawn conflict have all the resources they need to reassure themselves of the rectitude of their respective worldview.

It is not only the neat symmetry of (Islamophobic) 'Western' and (violent jihadist) 'Islamic' positions here that should prevent an uncritical counterposing of Isis iconoclasm and Western aesthetics. As complex material engagements in the field of visual culture, the transformations enacted in the name of iconoclasm require a careful attention to their specific character that does not take the claims of iconoclasts (or their antagonists) at face value. The Northern Iraq videos quite clearly involve not only their depicted acts of destruction but, in the widespread global circulation of those acts, a reinscription of the artefacts they ostensibly destroy. These brief, amateurish films lend themselves towards repeated viewing, reiterating the spectacle of vulnerable objects reduced to rubble. Replayed hundreds of thousands of times in news reports and social media, they multiply the audience for what were until then sometimes neglected remnants of human culture, hitherto unstolen from lightly-secured historical sites or gathering dust in undervisited museums. ${ }^{4}$ The Northern Iraq videos reframe and amplify the significance of these rocks and stones. As symbols and objects of contention, 
they live on in their new digital afterlives, encouraging us to reflect, as here, on the meanings that attach themselves to the mark of human culture.

To be concerned principally with the reception and interpretation of Isis iconoclasm by Western audiences and cultural institutions abstracts the defacement of historic artefacts from the broader context of mass murder and religious persecution in Northern Iraq. The iconoclastic desire to efface the mark of other cultures has clear affinities with Isis's genocide of Tazidis and Christians, and to treat the Northern Iraq videos in isolation from this context risks framing Isis as if they were simply engaged in some kind of harmless situationist joke (as satirized in Pan-Arabia Enquirer, 2015). While I do not accordingly want to play down the obvious connections between the Northern Iraq videos and their broader political-military function as a tactic of war, I should make clear that in what follows I do not set out to do justice to these connections. They are not what this article is about. My focus on the Northern Iraq videos turns inward to Western audiences and the question of why depicted acts of cultural vandalism seem to have such resonance. This decontextualization of Isis iconoclasm is, I think, inherent to the epistemological distance between Western audiences and contemporary events in Northern Iraq. While this framing might in part be down to an impassive or squeamish inability to face up to the awful human cost of jihadist violence (of which I am myself guilty), my suggestion is that it also tells us something significant about the cultural politics of preservation and postcolonial Western museum culture. It might be argued that there is something a little distasteful about this essentially Westocentric analysis, and 
I'm tempted to agree. Yet I also feel that the work of understanding the fascination with Isis iconoclasm is also a small part of the project of unpicking Westocentric narcissism too. If we want to value human life over bits of stone, we need to understand why we seem to care about those bits of stone so very much.

Figure 2 around here: screengrab from unite4heritage.org

\section{The conditions of preservation}

Whether it was intentional or not, Isis iconoclasm certainly gained the attention of the Western news and social media, as well as the swift condemnation of the 'global art community' (Rohdan, 2015). A Unesco press briefing convened a day after the release of the Mosul museum video described this 'tragedy' of 'cultural cleansing' as 'an issue of major security' and urged its prosecution as a war crime (UN News Centre, 2015). In March 2015 Unesco subsequently launched its social media campaign \#unite4heritage from the Iraqi capital Baghdad aimed at building 'support for the protection of heritage in areas where it is threatened by extremists'. In a quotation superimposed on the image of a relief panel from Nimrud and prominently featured on the campaign website, the Director General of Unesco, Irina Bokova, suggests that: 
Cultural sites have a universal value - they belong to all and must be protected by all. We are not just talking about stones and buildings. We are talking about values, identities and belonging. (Unesco, 2015a).

Despite the moral dilemmas that such sentiments provoke when they appear to value the artefacts of culture over human life (see, for example, J. Jones, 2015), Unesco seeks to make a necessary connection between political and cultural violence. Elsewhere, Bokova claims an 'indivisible link between cultural diversity and human rights' (Unesco, 2015b), describing the destruction of heritage as part of a strategy to 'destabilize and manipulate populations' (UN News Centre, 2015). Though Bokova's declaration of 'universal value' elaborates on the one hand a reading of cultural heritage as exemplifying characteristics of human nature (where 'cultural diversity $[\ldots]$ is the symbol of free thought and the infinite creativity of the human being' (Unesco, 2015b)), this universal heritage is simultaneously understood as a resource with specific significance for particular groups in particular places. ${ }^{5}$ This is a vacillation that registers an apparent transition in the understanding of the artefacts of heritage from their status as the desired objects of colonial modernity (acquired without a great deal of thought for the contemporary cultures from which they are obtained) to their status as local, regional and national resources in identity economies that develop around a commodified ethnicity (Comaroff and Comaroff, 2009). ${ }^{6}$ This transition is more apparent than real because in truth such identity economies are already invariably enmeshed in a complex that includes international tourism, the illicit, legal and 
paralegal trade in antiquities, and the big international museums as the clearing houses of cultural value. What heritage as a bearer of 'cultural diversity' means is, in short, brokered on a global stage where Western institutions continue to play a dominant mediating role. Finbarr Barry Flood suggests that it was in recognition of this disproportionate Euro-American power over historical artefacts that the Bamiyan Buddhas were destroyed by the Afghan Taliban in March 2001, iconoclasm serving as 'a form of protest against exclusion from an international community in which the de facto hegemony of the elite nations is obscured by the rhetoric of equal values' (Flood, 2002: 653). ${ }^{7}$

To place Isis's jihadist iconoclasm in this context does not require us to reductively read such practices simply as a reaction to or a provocation of Western interests, but it does encourage reflection on and questioning of the benign character we might otherwise attribute to intentions to protect and preserve cultural heritage. The account of Austen Henry Layard of the excavations at Nineveh in the early to mid-nineteenth Century is testament to the fact that the earliest involvement of the science of archaeology in Northern Iraq was in many respects a clumsy and destructive process. Layard describes how excavated artefacts are reduced to rubble on exposure to air, destroyed by iconoclasts, dropped to the ground, broken and 'much injured' in transit (Layard, 1857: 9, x, 292, 276, 99). The destructiveness of archaeology runs deeper than such accidents. Like the 'slow violence' of modernization and looting (Bohrer, 2015), the practice of archaeology leaves an irrevocable mark on the things that it touches. As has long been recognized within the 
discipline, 'excavation is destruction' (Wheeler, 1954: 15): the craft of archaeological fieldwork involves the irreversible transformation - and partial obliteration - of the materials it works on. In this respect, archaeology can be considered a kind of iconoclasm, where revelation and destruction are intertwined in the very same process.

Another way of thinking about the iconoclastic dimensions of practices of discovery and protection draws attention to their contextual displacement of the artefacts of cultural heritage. From the start, archaeology and its technologies of preservation have disrupted longstanding cultures of cohabitation and turned museums and heritage sites into 'no-go zones' (Colla, 2015a). The apparently self-evident virtues of heritage's protection - the defence of the past against its erasure - must be nuanced by a recognition that this is the past as revealed by the practices, methodologies and institutions of a Western-oriented heritage industry. The preservation of the past is not a disinterested archiving process, but one that effects a colonization of that past as the artefacts of history come to be filtered through the epistemologies and institutions of the West. However reverently and sensitively this is done, archaeology and its attendant processes effect a significant de- and recontextualization of cultural artefacts. A campaign like \#unite4heritage, as well as the policies and practices that underpin it, reveals a curatorial orientation where cultural heritage, in order to be read as symbolic of the universalized value of 'diversity', must submit to the authority of its curators. While Isis's purging of idols may certainly be read as militantly monotheistic (see Mitchell, 1994, chapter 9), the defence of idols in the name 
of pluralism is a long way from being a benign and disinterestedly polytheistic practice. Echoing its precedents in the colonial museum, the contemporary protection and preservation of assembled differences entails a monotheism at one remove, a meta-singularity that presides over and channels cultural heritage in particular directions. These transformations take place not through the physical destruction or defacement of objects, but through their careful preservation. They involve a violence effected through the deployment of the cotton glove, archival box, and protective scrunch of acid-free tissue paper. Long-registered in indigenous claims over Western museum collections (Mugabowagahunde, 2015), this violence is harder to register in contexts like Northern Iraq where the most visible and vocal engagements with the artefacts of heritage are those apparently intent on reducing them to dust. But the practice of preservation is an iconoclasm nonetheless: it is a nonphysical destruction through conservational estrangement. Like hunting trophies, museum artefacts index life but reference most emphatically their removal and distance from it.

Figure 3 around here: visitors in front of a Neo-Assyrian Lamassu at the British Museum

The Assyrian artefacts stripped from Northern Iraq by Layard and his contemporaries continue to be displayed in museum collections the world over. ${ }^{8}$ Artefacts from Nineveh and Nimrud fill numerous rooms in the British Museum, the Louvre and the Metropolitan Museum of Art. Like more famously contested artefacts (such as the Bust of Nefertiti or the Parthenon marbles), 
these spoils of colonial pasts persist uneasily into the present. While the confidence of modernist knowledge claims might have placed scientific discovery ahead of the persistence of objects per se, today the persistence of objects is all. Their protection and preservation have become the only available means of rationalizing the continued presence of ancient patrimony in the great imperial reliquaries of the West. Today Western museums promise survival into perpetuity so long as artefacts are subject to their radically decontextualizing terms and conditions. ${ }^{9}$

To recognize the violence of this form of preservation - and, not unrelatedly, the ways in which Western archaeologists and museum curators have been and continue to be implicated in a long history of 'artefact interventionism' (Colla, 2015b) - does not depend on us talking up the activities of the global heritage industry as uniformly and equivalently crypto-imperialist. This would be to diminish and misrepresent the ways a range of different actors - by no means necessarily confined to the West and 'Western interests' (however we characterize them) - might draw on the resources of cultural heritage now, in the past, or in the future. Cultural heritage is not an elapsed site of political struggle, and claims on heritage are not necessarily fatally compromised by Western influence over it. In the case of Northern Iraq ancient artefacts can and do give life to alternative contemporary ethnic and religious imaginaries, and in this sense Unesco's defence of cultural heritage as an emblem of 'diversity' is not without meaning, however legitimate our critique of its authority might be. But it nevertheless remains important to acknowledge the extent to which the institution of the museum and the terms of its preservation 
become the conditions of possibility for the artefacts of cultural heritage; that these conditions of possibility necessarily impede alternative practices that might depart from the primary injunction to preserve and conserve, for artefacts to exist and persist, to be treated with careful reverence by whoever it is who has jurisdiction over them as the custodians of historical sites or assembled collections. The artefacts of heritage must not be used, lived with or amongst in any way that might place their survival at risk; they must not be reworked or repurposed because this would jeopardize their integrity; they must not be reburied unless reburial is the condition of their survival; they must not be forgotten; above all, they must not be destroyed.

\section{The touch of iconoclasm}

It is this cardinal commitment to the material persistence of heritage artefacts that gives a special power to the Northern Iraq videos. Their depicted acts of destruction speaks speak directly to the culture of preservation. Their iconoclasm is an ironic and excessive rebuttal of the museum's printed injunction 'do not touch'. Such extravagant violations of visitor policy might be said to reveal the religious character of the first commandment of Western museum culture. 'Do not touch' is the manifestation of an idolatry that is suppressed beneath secular rationalizations of 'aesthetic awe' (Gell in Flood, 2002: 652). The Northern Iraq videos hold our attention not only because they tap into this reservoir of religious feeling, but also because they feed off our ambivalence towards the practice of touching. However aghast we may be at 
the iconoclasts' destruction, we remain in thrall to their theatre of extreme touching, for despite our respect for the protocols of museum etiquette, touching is what we all, secretly, want to do. As good museum visitors, we might hold ourselves back, aware that our fingertips transmit residues of sweat and oil that will pollute and damage the hardest of stones. But abstinence from touch further enhances our desire for it: it is surely no accident that variations of the phrase 'do not touch' are the most common texts to be found on museum walls. For who hasn't thrilled as they've allowed the back of their hand to surreptitiously brush against an artefact that has been designated beyond reach? Who hasn't felt in such encounters a resonance that is unavailable in the practice of looking alone? Who hasn't felt deprived of something by the reverential materialism of the museum that has the perversely immaterial effect of treating physical artefacts as if they were merely three-dimensional images ${ }^{10}$

Figure 4 around here: text panel at the British Museum

Phenomenologically-inclined theories of material culture recognize the significance of touching not just a source of illicit pleasure but a pathway of embodied perception. It is the distancing brought about by the insistent separation of the visual from the tactile that defines an artefact in its 'objectness' (see Ingold, 2011: 215). Artefacts treated as objects are hereby denied a life in their removal from our touch. Touch is not something (human) subjects 'do' to (inanimate) objects, but rather emerges in the circular interaction 'of the touched and the touching' 'such that the touch is formed in 
the midst of the world and as it were in the things' (Merleau-Ponty, 2000: 172, 166). According to such a perspective, 'do not touch' emerges as an important technology of a modern subject/object dualism, allowing both the museum visitor and the museumological artefact-object to come into being. Our prevailing desire to touch is testament to the incompleteness of our interpellation as detached and disembodied subjects of modernity. ${ }^{11}$ It also explains why the Northern Iraq videos are so arresting to watch: even in their destructive violence, they reminds us of the touch that the museum denies us; they remind us of something we are missing out on.

\section{Figure 5 around here: screengrab from the Nimrud video}

What we are watching in the violent touch that the Northern Iraq videos stage for us is of course the repeated breaking of stones. Take the sequence that features the Nimrud reliefs in the second video: a sledgehammer smashes into the upper arm of a supernatural figure and pulverised stone falls to the ground or lifts into the air. The facial profile of another winged figure is hammered from behind and a chunk of sculpted profile falls forward towards the camera. Sections of relief featuring human figures and carefully sculpted tree forms are cut away from metal supports and crash to the ground, knocking against the posts of a visitor guard chain which dances uselessly in the rising dust. This is stone that bears the mark of human culture nearly three thousand years old, yet it breaks before our eyes like stone that has been freshly quarried. In the act of effacing the mark of ancient human culture, the violent touch of the iconoclasts releases something new within the stone, 
revealing fresh surfaces unpatinated not only by the last three millennia of their time as relief panels at Nimrud, but by the longer geological time of their formation as a sedimentary gypsum in the Miocene somewhere between 5-23 million years ago (Jassim et al. 1997). ${ }^{12}$

\section{Figure 6 around here: screengrab from the Nimrud video}

It is my suggestion that the iconoclastic practice of making new incisions to these stones is a touch that comprises a radically new and transformative engagement with artefacts that had been turned into museum objects. In their defacement of the marks of Neo-Assyrian culture the iconoclasts echo the practice of the masons and sculptors who first cut away at the stone to mine, dress, and decorate it. These two moments of touch with the same piece of stone, separated by millennia, are accordingly brought into proximity as the first and last (or perhaps just most recent) human engagements with it. The touch of the icon maker and the iconoclast describes an intimacy between them. While the touch of the former served to extend Neo-Assyrian culture into a distant future, the touch of the latter is a vivid connection back to the stone's cultural inception. By revealing the inside of the stone hitherto concealed from human sight, both moments of touch also engage the historicity of the stone itself. As an expression of its intrinsic materiality, this third originary moment in the life of the stone is implicit to the act of purposive

working upon it, irrespective of how it is understood by whoever is engaged in that practice. The cuts that human touch makes in stone are cuts in time, temporary stabilizations in the flow of life around which meaning develops 
(see Zylinska, 2014 38-9). These temporal markers in the life of the stone locate themselves by referring backwards and forwards, to the stone's past, present and future. Their juxtaposition reveals the time of the stone to be polychronic and multitemporal, 'gathered together with multiple pleats' (Serres in Muecke, 2004: 10).

Of course artefacts of human culture do not need to be defaced or destroyed to serve this function. As Katrina Schlunke has suggested of the 'declared objects of colonialism', museum artefacts have a cultural productiveness that may disrupt their containment within prevailing epistemological frameworks. Their endurance as valued objects means that they remain a resource for any number of future contestations (Schlunke, 2013). In this sense, all cultural artefacts have, in Walter Benjamin's terms (1999), a weak Messianic power over unforeseen future circumstances that might redeem them. While it might accordingly be argued in the case of the Northern Iraq videos that the physical destructiveness of Isis iconoclasm negates this future potential, this would be to slip back into a reading of iconoclasm that takes the word of the iconoclasts at face value. For in fact whatever becomes of the stones themselves, the actions that defaced or destroyed them have their own promissory character, not just by the medium of the Northern Iraq videos, but then also layering subsequent engagements with the many thousands of artefacts extracted from Northern Iraq and held in public and private collections the world over. In the case of the Nimrud reliefs, this includes substantial collections in London, New York and elsewhere which repeat precisely the same motifs as those depicted in the second video, including the supernatural figure shown in the 
video being attacked with a sledgehammer (for more on the repetition of these figures and their global dispersal, see Robson, 2015). While in this case particular reliefs of this particular figure have been lost, virtually identical iterations of the same relief survive, undoubtedly taking on renewed significance as a result. The iconoclastic destruction of artefacts of NeoAssyrian culture may be a loss in quantitative terms but a gain in terms of its audience and value. This in turn will have a likely effect on the resources available to its study in the future, with implications for archaeology that remains in the ground.

\section{The touch of stone}

In the case of the Northern Iraq videos, iconoclasm's tendency to become undermined by its inherent self-contradiction does nothing to break the 'preferred reading' that their narrations set out. Indeed, it further reinforces the binary logic of desecration/conservation, serving to strengthen not only the apparent differences between Isis and its symbolic antagonists, but also (and more damagingly) encouraging the idea of a fundamental attitudinal or conceptual distinction between Muslims and non-Muslims (see Pitcher, 2014: 135-9). Yet a focus on touch's capacity to animate a relationship between human beings and cultural artefacts opens up further critical possibilities far removed from the usual divisive exaggerations of 'civilizational' incompatibility. It draws our attention once more to the violence of the museum, and what the technology of 'look, but don't touch' says about a cultural formation whose prevailing concern is with heritage's protection and preservation. 
We don't have to elaborate a universal ontology of human-material relations to recognize - as I have just done in my reading of the Northern Iraq videos the way in which stone has a special cultural significance to human beings as a marker and repository of time. Stone's physical properties, expression of the geological time of its formation, are what in turn serve as the medium of enduring cultural inscription. When we leave our mark on rocks and stones we piggy-back onto their capacity to channel 'deep history' (Chakrabarty, 1999). While we are now beginning to recognize how humanity imprints itself in the long-term changes it brings about to the earth's climatic conditions, fossil record and exosphere ${ }^{13}$, the mark of premodern human culture has hitherto been predominantly visible in cuts to earth and stone. Though stones might be indifferent to the human, we share our presence with them as they bring to life absent others. By simultaneously bearing the inscription of human touch and the longue durée of geological time, stones serve as points of mediation between transient lives in transient cultures and the geological ground on which they unfold. 'Considering the human within geologic time poses the problem of thinking an inhuman milieu, both before, after and internal to "us"' (Yusoff, 2015: 388). Brokering the finite and the infinite, stones of course play a central role in creation myths as the rock, clay or dust that becomes human life (Sax, 2011: 23-4). Humanity has always described - etymologically as well as metaphysically, 'a connection with the humus' (Harrison, 1994: 361; see also Haraway, 2015: 259), and stones capture this fundamental relationship between human life and the earth. ${ }^{14}$ All cultures draw on these resonances, and this includes Islamic cultures of course. Consider the pilgrim- 
worn rock of the cave on Mount Hera where Muhammad received the Quran, or the ritual kissing of the black stone embedded in the Kaaba at the centre of Mecca's Grand Mosque.

I note these last two examples both because they refuse the Islamophobic logic of civilizational incompatibility and return us to the phenomenology of touch. In his reflection on stones marked by prehistoric cultures, Christopher Tilly suggests that both totemic (sign-based) and animistic (relational) systems of thought have their basis 'in the ordinary everyday bodily understanding that human beings are part of a world, an environment, a landscape, rather than radically separated from it'. For Tilly, our 'primordial preconceptual experience of the world' is a synaesthesic one. Perception involves the simultaneous use of the senses, not their isolation from one another (Tilly, 2004: 20, 14). Tim Ingold elaborates on these immersive, embodied, sensual engagements within our world of materials as a precondition of interaction and engagement, where 'humans figure as much within the context for stones as do stones within the context for humans'. By cutting stones out of this immersive context, they would be 'reduced to objects - they would be dead' (Ingold, 2011: 41, 93). Stones marked by human culture are, we might plausibly suggest, meant to be touched, and by removing them from our touch we remove them from our world. Though the acts of cultural vandalism depicted in the Northern Iraq videos are hardly an ideal model of synaesthesic practice, their desecration nevertheless effects a deobjectification: iconoclasm gives artefacts a new life by drawing them back into the world of human touch. The lifeless museum objects labelled 'do not 
touch' and defined by the distance and detachment of an 'optical relation between mind and world' are revivified though haptic engagement, and, even in their destruction are, reintegrated into 'the textures of the world'. (Ingold, 2011: 133).

The phenomenological insights I sketch out here are now widely acknowledged in the art world where artists and curators alike have sought to cultivate synaesthesic engagement, feed off the excitement generated by the transgression of 'do not touch', and play with the iconoclastic dynamics of destruction and value. They are there, too, in contemporary museum culture, where plural sensory engagements are recognized affording rich learning experiences (Wood and Latham, 2011; Walker 2013). Important differences of course remain: in the case of museums artefacts, handling materials are largely palliative in nature: sturdy, common and low-value items are deployed to protect those of greater scarcity and value (Candlin, 2004: 72). This petting zoo approach to cultural artefacts effectively facilitates a touching that reinforces the logic of 'do not touch' and its separation of subjects from objects. We are permitted to go so far, but not further, in our physical engagement with museum collections. The appropriate white-gloved touch of curators confirms their quasi-religious status as clergical intermediaries between sacred objects and a grubby-handed public (ibid., 79). ${ }^{15}$ The strict maintenance of the museum's separation of subjects and objects in our reflexive, immersive and interactive culture makes absolute sense according to the abiding logic of protection and preservation. This is the same logic that is rationalized in Unesco's linking of cultural heritage and cultural diversity, 
and its hegemony is of course what makes Isis iconoclasm so affecting. In the last part of this discussion I want to question its common sense, not in order to champion a facile iconoclastic alternative but to provide a way of thinking about why iconoclasm's hold is so strong.

\section{The revenge of objects in postcoloniality}

In psychoanalytic readings that develop Freud's sketch of 'Character and Anal Eroticism' (1989), the practice of collecting is linked to a neurotic desire for control. The subject extends themselves into the objects they have collected, and their psychological stability is dependent on the maintenance of the collection. In Jean Baudrillard's account, collected objects 'imbued with self and removed from time' become a way of dealing with the singularity of human life. While collections do not make the subject immortal, they offer a synchronic respite from relentless diachrony, a consoling symbolic transcendence of 'our anxieties about time and death' (Baudrillard, 1994: 16, 17). Although I don't think it is particularly useful to attempt a wholesale transposition from individual to collective, it is interesting to think about museum culture as a variety of hoarding, and to consider how the preservationist logic of 'do not touch' might provide a mechanism of stabilization for the culture of which it is an expression.

We are used to the idea that the imperial-era accumulation and maintenance of the world's cultural heritage in Western museums (and particularly the great national collections) worked as tribute to and glorification of those empires. The collection and curation of the artefacts of other cultures permitted a range 
of distinctions that threw a flattering light on the culture doing the assembling, telling self-serving stories about the extent of its power and sophistication. Heritage collections slotted into imperial and racial epistemologies of classification and control. Collected objects stood for historical and geographical others, and lent moral, scholarly and aesthetic coherence to imperial regimes that would otherwise be more keenly marked (and degraded) by their explicit, unpalatable violence and exploitation. As I suggested earlier, these practices might be said to effect a colonization of the past where preservation has itself through its contextual displacements a violent and iconoclastic dimension. It would not be wrong to suggest that there are significant present-day continuities at work here, and it is important not to play down the ways in which a Western-oriented heritage industry continues to shore up a narcissistic self-image of Western subjects as the protectors and defenders of the world's culture (see, for example, Duthie, 2011).

But the Northern Iraq videos encourage a reflection that moves us on a little from this model of collection as a mode of controlling imperial subjectivation. There is a postcolonial afterlife to think of here that is certainly characterized by some of the same practices - indeed, that has seen a considerable reinforcement of the respectful logic of 'do not touch', but which might also be said to describe a different collective orientation to the artefacts that 'do not touch' preserves. The museumological objects that played a role in defining the subjects of Western modernity now animate some of the abiding issues of postcoloniality, particularly around issues of cultural ownership. They trouble the civilizational and geopolitical border work that continues to work through 
material heritage, for the 'declared objects of colonialism' are 'insistent and persistent things [...] and their effects are pervasive and disruptive' (Schlunke, 2013: 18). The objects that museums dedicate themselves to preserving and displaying have become a continual material testimony to the inappropriateness of their own presence. Once assimilated to the ideal subject of Western modernity, they are no longer in the West's legitimate possession. Like good food that has spoiled over time, these are objects gone sour. They are captives that turn against their captors; slaves that indict their owners. 'Do not touch' guarantees the indefinite persistence of these objects that have become incommensurable and out of place. It guarantees that they will remain a present reminder of an illicit and unacceptable past, permanently troubling the cultures that have grown out of it. Even as the work of geopolitically 'progressive' curation grows ever more emphatic in its intended cultural politics, ${ }^{16}$ the objects of others' heritage question its proprietorial and custodial assumptions. In short: where once Western subjects were consolidated by the collection and display of the patrimony of other cultures, now this heritage serves as an embarrassment that cannot be got rid of. Worse still, the injunction to conserve and protect means that the very existence of cultural heritage entails a permanent relationship of obligation towards it. It cannot be ignored or abandoned; it must be preserved.

Is there something pathological about the way that the artefacts of cultural heritage so emphatically demand our attention, but which then receive an attention that contains and distances them? Ever more careful and reverent approaches to protection and preservation in the current historical moment 
could, it might be argued, be motivated by the desire to maintain artefacts in their status as dead objects. 'Museum and mausoleum', wrote Adorno, 'are connected by more than phonetic association. Museums are like the family sepulchres of works of art. They testify to the neutralization of culture'. (Adorno, 1981: 175). The distancing violence of 'do not touch' maintains a passifying cordon between the museum visitor and the objects of the past, its sensual deprivations serving to lessen the recognition that the museum's hold on cultural heritage is an illegitimate one (is it somehow less incriminating to look at looted culture from behind cabinet glass than it is to touch it?). We might speculate that this distancing could also be motivated by an underlying fear of losing these objects (and with it the ambivalent mastery that their possession signifies) to the demands of others who might have other, or better uses for them. The sensuality that we might impute to both the religious worship and destruction of icons is nowhere to be seen. Instead, idolatry and iconoclasm are fused together in curatorial paralysis: we are alienated from the objects we do not allow ourselves to touch. What if protection and preservation - in denial of their own violence and in thrall to their self-serving magnanimity - actually conceal within them the desire to both hold onto these troublesome objects and make them go away? Could it be that protection and preservation mask a subliminal negatory urge, a jealous possessiveness that would rather suck the life from objects rather than give them up? If so then might Western audiences ultimately find the destructive violence of the Northern Iraq videos so captivating not because it liberates historical artefacts from their slumber as dead objects, but because Isis iconoclasm signals a 
momentary respite from the deadlock of a obsessive neurotic hoarding set in train by the tyrannical logic of Western modernity?

\section{NOTES}

${ }^{1}$ Here, and in what follows, jihadism refers specifically to the violent practices of contemporary militant Salafist groups and their followers rather than the wider Islamic concept of jihad (Farid Mirbagheri, 2012, chapter 3; O'Rourke, 2012).

${ }^{2}$ If depicted acts of Jihadist violence remind us of performance art, this is because they frequently shares a common language of both medium (cheap video) and form (untrained actors in semi-improvisational scenarios).

${ }^{3}$ The homosocial spectacle of urgent physical engagement with illicit human and animal forms suggests that there are considerable libidinal energies at work in this violence. The iconoclasts' physical consummation with denied objects suggests a form of Agalmatophilia (sexual attraction to figurative objects like statues). The erotic aspects of iconoclasm again point to the sense in which it can be understood as an activity that is both destructive and productive, an engagement with objects that is animating and intensifying (see Smith, 2013: 61). This stands in stark contrast to the dispassionate distancing of Western museum culture, a point to which I will later return.

${ }^{4}$ I don't want to reflect here on the question of value per se. The Isis videos appear to depict the destruction or defacement of a range of different kinds of object, ranging from those of immense rarity and historical value to comparatively worthless plaster casts. Debate in the Western media around Isis iconoclasm has included a lot of speculative discussion of the group's alleged involvement in the illicit trading of looted artefacts, and is often framed in terms of an economic pragmatism hidden beneath a publicity-oriented veneer of religious piety. Needless to say, my interest here in the depicted acts of iconoclasm is not a comprehensive attempt to understand the calculations that may have preceded them or the broader cultural and political economy of antiquities. Nor will it try to weigh up the incidence of iconoclastic practice relative to alternative practices of ignoring, preserving, or trading in cultural artefacts.

${ }^{5}$ In the example of Northern Iraq, it is the opponents of Isis including Shiite Muslims, and a range of religious and ethnic minorities such as the Yazidi Kurds, Christians, and Shabakis who are implicitly positioned in this role. 
${ }^{6}$ Marking Britain's belated intention to ratify the 1954 Hague Convention, UK Culture Secretary John Whittingdale is quoted as saying that 'The loss of a country's heritage threatens its very identity' (Helm, 2015).

${ }^{7}$ This is a frame we might also deploy to understand and interpret the International Criminal Court's first ever prosecution in September 2016 of attacks on historic monuments in Timbuktu as war crimes, a recent marker of the increasing significance of cultural heritage on the global stage (ICC, 2016).

${ }^{8}$ See, for example, the catalogue of 76 museums holding material from Nimrud at

http://oracc.museum.upenn.edu/nimrud/catalogues/museumsworldwide/index. html

${ }^{9}$ There is another story to be told here about the development of more sophisticated curatorial approaches to artefacts that allow them a life outside of modernist epistemology, which do not presume that any knowledge can be total or any meaning final, and which encourage the development of plural, unorthodox, open and alternative engagements with them (see, for example, Crang and Tolia-Kelly, 2010: 2327-8). But it is worth recognizing that these modest and more politically defensible orientations depend upon - and are substantially undermined by - the priority of the culture of preservation I am describing here.

${ }^{10}$ Fittingly perhaps, an EU funded 'response to the destruction of cultural heritage by the Islamic States' uses crowd-sourced photos 'to virtually recreate artefacts as 3D objects using the latest in photogrammetry techniques'. These objects can be digitally manipulated in the 3D viewing platform Sketchfab, in which apparently solid forms can be flipped over to their insides, revealing that they are composed from an untouchable pixelwidth of topographically modelled electronic skin (See http://projectmosul.org). In May 2016, the high-profile replication in London of the Roman 'Arch of Triumph' at Palmyra in Syria by The Institute for Digital Archaeology (a joint venture between Harvard University, the University of Oxford and Dubai's Museum of the Future) is another example of investment in digitization and 3D technology as a response to Isis iconoclasm. For a discussion of the uses to which digital aftefacts have been put by indigenous communities, see Newell (2012).

${ }^{11}$ For an historical overview of the rise of the visual and the fall of touch in Western museums, see Classen and Howes (2006).

12 The recognition that 'old' stone breaks just like 'new' stone foregrounds the way in which its inherent geological time surfaces and recedes in our consciousness. Mostly, we choose to forget stone's pre-cultural geological history - it is a blank canvas (a 'clean slate'), considered 'nothing more than the unworked material support' (Krauss in Mitchell, 2012: 45) of aesthetic practice awaiting the mark of human culture. Some of the resonance of lithic 
artefacts depends on this blankness: we can imagine the clay of the prehistoric figurine is the same as the clay we can ourselves dig and handle, but this is a historicity that depends on our backgrounding the deep history of the clay itself. It worth noting that some canvases are blanker than others, and freshly quarried stone can be imbued with culture by association. Consider the cultural politics of Britain's Daily Mail in its cultivated outcry over the signing of a letter of intent that would give the Bin Laden family a controlling share of the company that mines the Fantiscritti quarry in Tuscany, source of 'the creamy white stone [...] selected by Michaelangelo to give form to Christianity's most cherished characters, including his masterpiece, David.' (Roberts, 2014).

${ }^{13}$ For an account of the space junk that will be suspended for billions of years in geostationary orbit, see Ellsworth and Kruze (2013), chapter 22.

${ }^{14}$ The Northern Iraq videos elicit and amplify stone's metaphysical qualities as they depict its transformation to dust. They stage a process of erosion and decomposition that references in accelerated form the inevitable workings of geological time.

\section{${ }^{15}$ ADDED NOTE to add in at proof stage or before}

These official delineations are softened somewhat in Fiona Candlin's assessment of museum attendants as tolerant and understanding of visitors' persistence in 'unauthorised touch' (2017).

${ }^{16}$ Consider the homilies about the peaceful historical coexistence of Islam, Judaism and Christianity that currently appear to be a fairly obligatory way of framing contemporary historical exhibitions on the Middle East (see, for example, Kennedy, 2015). 


\section{References}

Adorno T (1981) Prisms. Cambridge, Massachusetts, MIT Press.

Baudrillard J (1994) The system of collecting. In Elsner J and Cardinal R (eds) The Cultures of Collecting. Cambridge, Mass: Harvard University Press, pp.7-24.

Benjamin W (1999) Theses on the Philosophy of History. In Illuminations. London: Pimlico, pp.244-55.

Bohrer F (2015) The Destruction of Art and Antiquities in Our Time. In LA Review of Books. Available at: https://lareviewofbooks.org/essay/thedestruction-of-art-and-antiquities-in-our-time (accessed 18 January 2016).

\section{ADD IN}

Candlin F (2017) Rehabilitating unauthorised touch or why museum visitors touch the exhibits. The Senses and Society, 12:3, 251-66

Candlin F (2004) Don't Touch! Hands Off! Art, Blindness and the Conservation of Expertise. Body \& Society 10(1): 71-90.

Chakrabarty D (1999) The Climate of History: Four Theses. Critical Inquiry, 35(2): 197-222.

Classen C and Howes D (2006) The Museum as Sensescape: Western Sensibilities and Indigenous Artefacts. In Edwards E, Gosden C and Phillips RB (eds) Sensible Objects: Colonialism, Museums and Material Culture. Oxford: Berg, pp.199-222.

Colla E (2015a) On the iconoclasm of Isis. In Baghdad Central. Available at: http://www.elliottcolla.com/blog/2015/3/5/on-the-iconoclasm-of-isis (accessed 18 January 2017).

Colla E (2015b) Preservation and destruction. In Baghdad Central. Available at: http://www.elliottcolla.com/blog/2015/3/27/pm0t4j35d00plvir68mkffl6fyquh0 (accessed 18 January 2017).

Comaroff J and Comaroff J (2009) Ethnicity, Inc. Chicago: University of Chicago Press.

Crang M and Tolia-Kelly DP (2010) Nation, race, and affect: senses and sensibilities at national heritage sites. Environment and Planning A, 42(10): 2315-31.

Duthie E (2011) The British Museum: An Imperial Museum in a Post-Imperial World. Public History Review, 18: 12-25. 
Ellsworth E and Kruse J (eds) (2013) Making the Geologic Now: Reponses to the Material Conditions of Contemporary Life. New York: Punctum Books.

Farid Mirbagheri SM (2012) War and Peace in Islam: A Critique of Islamic/ist Political Discourses. Basingstoke: Palgrave Macmillan.

Flood FB (2002) Between Cult and Culture: Bamiyan, Islamic Iconoclasm, and the Museum. The Art Bulletin, 84(4): 641-59.

Freud S (1989) Character and Anal Eroticism. In Gay P (ed.) The Freud Reader. London: WW Norton, pp.293-6.

Haraway D (2015) Anthropocene, Capitalocene, Chthulhucene. In Davis H and Turpin E (eds) Art in the Anthropocene: Encounters among Aesthetics, Politics, Environments and Epistemologies. London: Open Humanities Press, pp.255-70.

Harrison, RP (1994) Hic Jacet. In Mitchell WJT (ed.) Landscape and Power. Chicago: University of Chicago Press, pp.349-64.

Helm T (2015) Britain signs convention on protecting treasures in war zones, Guardian. 21 June. Available at:

http://www.theguardian.com/world/2015/jun/21/britain-signs-up-to-protect-

cultural-treasures-war-zones (accessed 18 January 2017).

Ingold T (2011) Being Alive: Essays on Movement, Knowledge and Description. Abingdon: Routledge.

ICC (2016) 'Al Mahdi Case', available at: https://www.icc-cpi.int/mali/al-mahdi (accessed 28 July 2017).

Jassim S, Jibril A and Numan N (1997) Gypsum kaxstification in the Middle Miocene Fatha Formation, Mosul area, northern Iraq. Geomorphology 18: 137-49.

Jones C (2015) What is ISIS' Media Strategy? Gates of Nineveh. Available at: https://gatesofnineveh.wordpress.com/2015/04/22/what-is-isis-media-strategy/ (accessed 18 January 2016).

Jones $\mathrm{J}$ (2015) Palmyra: is saving priceless antiquity as important as saving people? Guardian, 19 May. Available at:

http://www.theguardian.com/artanddesign/jonathanjonesblog/2015/may/19/pal myra-syria-islamic-state-architecture-protected (accessed 18 January 2017).

Kennedy M (2015) British Museum to train Iraqi curators in heritage protection. Guardian, 28 October. Available at: http://www.theguardian.com/culture/2015/oct/28/british-museum-to-train-iraqicurators-in-heritage-protection (accessed 18 January 2017). 
Latour B (2002) What is iconoclash? Or is there a world beyond the image wars? In Iconoclash: Beyond the Image Wars in Science, Religion, and Art. Karlsruhe: Zentrum für Kunst und Medientechnologie, pp. 16-38.

Layard AH (1857) A Popular Account of the Discoveries at Nineveh. Derby \& Jackson: New York.

Memri TV (2015a) \#4801 - ISIS Destroys Archaeological Treasures in Mosul. Available at: http://www.memritv.org/clip/en/4801.htm (accessed 18 January 2017).

Memri TV (2015b) \#4865 - ISIS Destroys Ruins of Ancient Assyrian City of Nimrud, Iraq. Available at: http://www.memritv.org/clip/en/4865.htm (accessed 18 January 2017).

Merleau-Ponty M (2000) The intertwining - the chiasm. In Cazeaux C (ed.) The Continental Aesthetics Reader. London: Routledge, pp.164-80.

Mitchell WJT (ed.) (1994) Landscape and Power. Chicago: University of Chicago Press.

Mitchell WJT (2005) The Unspeakable and the Unimaginable: Word and Image in a Time of Terror. ELH, 72(2): 291-308.

Mitchell WJT (2012) Seeing Through Race. Cambridge, Mass: Harvard University Press.

Muecke R (2004) Ancient \& Modern: time, culture and indigenous philosophy. Sydney: University of New South Wales Press.

Mugabowagahunde M (2015) African Indigenous Heritage in Colonial and Postcolonial Museums: The Case of the Batwa of Africa's Great Lakes Region. In Logan W, Craith MN and Kockel U (eds) A Companion to Heritage Studies. Chichester: Wiley Blackwell, pp.146-159.

Nancy J-L (2005) The Ground of the Image. New York: Fordham University Press.

Newell J (2012) Old objects, new media: historical collections, digitization and affect. Journal of Material Culture 17(3): 287-306.

O'Neil ME, Reinders E, Brubaker L, Clay R, and Boldrick S (2014) The new iconoclasm. Material Religion: The Journal of Objects, Art and Belief. 10(3): 377-85.

O'Rourke J (2012) Representing Jihad: the appearing and disappearing radical. London: Zed Books.

Pan-Arabia Enquirer (2015) 'The Islamic State wins prestigious Turner Prize for modern art', March 3. Available at: 
http://www.panarabiaenquirer.com/wordpress/islamic-state-wins-prestigiousturner-prize-modern-art/ (accessed 24 July 2017).

Probst P (2012) Iconoclash in the Age of Heritage. African Arts, 45(3): 10-13.

Roberts H (2014) Italian quarries that supplied creamy white stone for Marble Arch and Michaelangelo's statue of David to be sold to Bin Laden family. Daily Mail, 19 June. Available at:

http://www.dailymail.co.uk/news/article-2662694/Italian-quarries-suppliedcreamy-white-stone-Marble-Arch-Michaelangelos-statue-David-sold-BinLaden-family.html (accessed 18 January 2017).

Robson E (2015) The genies on the stairs: stone carvings in the Fitzwilliam Museum, Cambridge. In Nimrud: Materialities of Assyrian Knowledge Production, The Nimrud Project at Oracc.org. Available at: http://oracc.museum.upenn.edu/nimrud/livesofobjects/stonegenies/ (accessed 18 January 2017).

Rohdan M (2015) 'Global Art Community Condemns ISIS Destruction of Artifacts at Mosul Museum', Time. Available at: http://time.com/3725026/isisdestruction-mosul-museum-artifacts/ (accessed 31 July 2017).

Said B (2012) Hymns (Nasheeds): A Contribution to the Study of the Jihadist Culture. Studies in Conflict \& Terrorism, 35(12): 863-79.

Sax B (2011) What is this quintessence of dust? The concept of the "human" and its origins, in Boddice R (ed.) Anthropocentrism: Humans, Animals, Environments. Leiden: Brill, pp.21-36.

Schlunke K (2013) One strange colonial thing: material remembering and the Bark Shield of Botany Bay. Continuum: Journal of Media \& Cultural Studies. 27(1): 18-29.

Smith M (2013) The Erotic Doll: A Modern Fetish. New Haven: Yale University Press.

Taussig M (1999) Defacement: public secrecy and the labor of the negative. Stanford: Stanford University Press.

Tilly C (2004) The Materiality of Stone: Explorations in Landscape Phenomenology. Oxford: Berg.

UN News Centre (2015) 'Urging international action, UNESCO chief condemns ISIL's 'cultural cleansing' in Iraq', 27 February. Available at: http://www.un.org/apps/news/story.asp?NewsID=50205\#.WX8DcoqQwf4 (accessed 31 July 2017).

Unesco (2015a) unite4heritage website. Available at: unite4heritage.org (accessed 18 January 2017). 
Unesco (2015b) Message from Ms Irina Bokova, Director-General of UNESCO. Available at: http://www.unesco.org/new/en/unesco/events/prizesand-celebrations/celebrations/international-days/world-day-for-culturaldiversity-for-dialogue-and-development-2015_(accessed 18 January 2017).

Walker A (2013) Beyond the Looking Glass: Object Handling and access to museum collections. Unpublished PhD thesis, University of Southampton.

Wheeler M (1954) Archaeology from the Earth. Oxford: Harmondsworth: Penguin Books.

Wood E and Latham K (2011) The Thickness of Things: Exploring the Curriculum of Museums through Phenomenological Touch. Journal of Curriculum Theorizing. 27(2): 51-65.

Yusoff K (2015) Geologic subjects: nonhuman origins, geomorphic aesthetics and the art of becoming inhuman. Cultural Geographies 22(3): 383-407.

Zylinska J (2014) Minimal Ethics for the Anthropocene. Michigan: Open Humanities Press. 